\title{
Crop
Reports
}

\section{Calla History and Culture}

\author{
Jeff S. Kuehny ${ }^{1}$
}

\section{Additional INDEX words. Zantedeschia, botany, taxonomy, cultural require- ments, pests, postproduction, post- harvest}

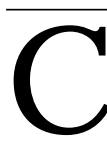

alla is a tropical plant native to Africa extending from Cape Province to Eastern 0 range F reeState, $\mathrm{N}$ atal, L Lesotho, Swaziland, Transvaal, Rhodesia, Malawi, Zambia, Angola, and into northern Nigeria (Letty, 1973; Tjia, 1985). The genus Zantedeschia was assigned to calla by Sprengel in 1826 in honor of I talian botanist Giovanni Zantedeschia (Letty, 1973).

There are many common names and several species. Common names include calla lily, pig lily, arum lily, aroid lily, zantedeschia, richardia, cape arum, cape lily, black-eyed arum, yellow arum, cuckoo-pint, jack-in-thepulpit, lily of the Nile (Funnell, 1993; H oogasian, 1992; T jia, 1985). O ther common names of calla include kleinvarkblom, varkblomme, varkore, aronskelke, persvarkoor, varkoorlelie, varkore (Funnell, 1993).

Assistant professor, D epartment of H orticulture, L ouisiana State U niversity Agricultural C enter, 137 Julian C. M iller $\mathrm{H}$ all, Baton Rouge, LA 70803-2120.

Approved for publication by the director of the L ouisiana Agricultural Experiment Station as manuscript no. 99-28-0290. Company, plant or chemical names are referred to for example only and it is not the intent of the author to promotetheuse of any particular brand or company. The cost of publishing this paper was defrayed in part by the payment of page charges. U nder postal regulations, this paper therefore must be hereby marked advertisement solely to indicate this fact.
The genus Zantedeschia is a part of the A raceae family. There are seven recognized species and two subspecies of Zantedeschia: Z. aethiopica (L.) Spreng., Z. rehmannii Engl., Z. jucunda Letty, Z. elli ottiana (Watson) Engl., Z. pentlandi i (Watson) Wittm., Z. odorata P.L. Perry, Z. albomaculata (H ook.) Baill. subsp. al bomaculata, Z. albomaculata (H ook.) Baill. subsp. macrocarpa (Engl.) Letty, and Z. albomaculata (Hook.) Baill. subsp. valida Letty. (Letty, 1973; Perry, 1989). Closely related genera are A glaonema Schott., Anthurium Schott., Caladium Venten., Dieffenbachia Schott., Epipremnum Schott., M onstera Adans., N ephthytis Schott., Philodendron Schott., Spathi phyllum Schott., and Syn gonium Schott. (Liberty $\mathrm{H}$ yde Bailey H ortorum, 1976).

Calla have two different types of storage organs (Funnell, 1992). Zantedeschia aethi opica have stemless rhizomes and are an evergreen species. The remaining species have compact stems or tubers and are deciduous. The leaves are entire and born on a long petiole. Theinflorescenceiscomposed of a fleshy spadix bearing the true flowers, subtended by a single showy spathe (Corr, 1993; Corr and Widmer, 1987; Liberty H yde Bailey H ortorium, 1976; Tjia, 1985).

Calla may be grown as outdoor garden plants, commercial cut flowers and more recently as flowering potted plants. Although this plant has not been widely grown commercially, there is an abundance of information on all aspects of calla and it continues to increase in popularity. Zantedeschia elliotiana, Z. aethiopica, and Z. rehmannii have been grown for cut flower production or outdoor garden plants for many years (Post, 1959).
Since the 1980s, research has been conducted to determine the feasibility of using Zantedeschia species as flowering potted plants. I $n$ addition, many calla hybrids have been bred for forcing as flowering potted plants (van Scheepen, 1991). Funnell (1993) provides a list of 61 species and cultivars commercially availableinternationally. About $50 \%$ of flowering size calla tubersare produced in the U nited States, The $\mathrm{N}$ etherlands and $\mathrm{N}$ ew Zealand produce $45 \%$ and I ndia, Sri L anka, and Central America produce 5\% ( $T$. Lukens, personal communications). I n the U nited States, more than $95 \%$ of calla are grown as flowering potted plantswhereasin Europeabout $80 \%$ to $85 \%$ are used as cut flowers.

\section{Genetics and cultivar development}

$\mathrm{N}$ atural species and hybrids of calla are diploid with 32 chromosomes (Cohen and Yao, 1996). There are a number of postfertilization incompatability barriers between species with most calla being self fertile. D evelopment in the U nited States has been concentrated in California, L uther Burbank made crosses within the genusZantedeschia and produced several new cultivars at the turn of the century (Welsh, 1991). I n the 1940sand 1950s Shibuya (1956), also in California, conducted extensiveintercrossing work with Z. rehmannii, Z. albomaculata, and $Z$. elliottiana. $H$ is breeding work produced spathe coloration covering almost the entire color scale along with variations in the shape and size of leaves and the tubers, the pattern and distribution of leaf spots, plant growth and plant heights. In N ew Zealand, breeding has been conducted by Brljevich of M aungaturoto in 1932, $M$ atthews of Waikanae started collecting and breeding in 1946, and $\mathrm{H}$ arrison conducted breeding in the 1960s (Welsh, 1991). The Brown family of Central $C$ alifornia began breeding calla in the 1940s; however, homogeneous seed strains were not readily obtained, and thenew hybridsweresold asmixed hybridsfor many years( Brown, 1990). The inability of growers to control bacterial soft rot [Erwinia carotovora subsp. carotovora (Jones) Bergey et al.] and poor seed collection, decreased demand, production and breeding in the 1960s and 1970s. Cultural techniques for preventing and suppressing disease infestation, the development 
of tissue culture, the development of true $F$, seed lines in the $U$ nited States and a demand for wide range of plants and flowers has revived the calla industry and breeding programs. Current breeding programs select for use as flowering pot plants and cut flowers. B reedersare using the existing hybrids and species and are breeding for: plant height, a large number of spathes (multibranching), spathe size, ease of culture, disease resistance, ability to force, fragrance, stem strength and post production longevity (Brown, 1990; De Hertogh, 1996; Funnell, 1993). Golden State Bulb Growers (Watsonville, Calif.) has, for example, introduced 12 new true $F_{1}$ hybrid seed lines over the last 10 years ( $T$. L ukens, personal communications). In addition, in vitro chromosomedoubling of calla by induction of polyploid strains has been reported by Cohen and Yao (1996). The combinations of these efforts will potentially increase the range of hybridsthat can be produced.

\section{Species and cultivars}

M ore than 10 species have been proposed for the genus Zantedeschia (Traub, 1948), later reduced to six (L etty, 1973). A recent addition brings the current number to seven (Perry, 1989), with two subspecies (Funnell, 1993; Letty, 1973). The species fall into two specific groups: 1) evergreen (plants with foliage that does not die down in the winter) and 2) deciduous (plants with foliage that dies to the

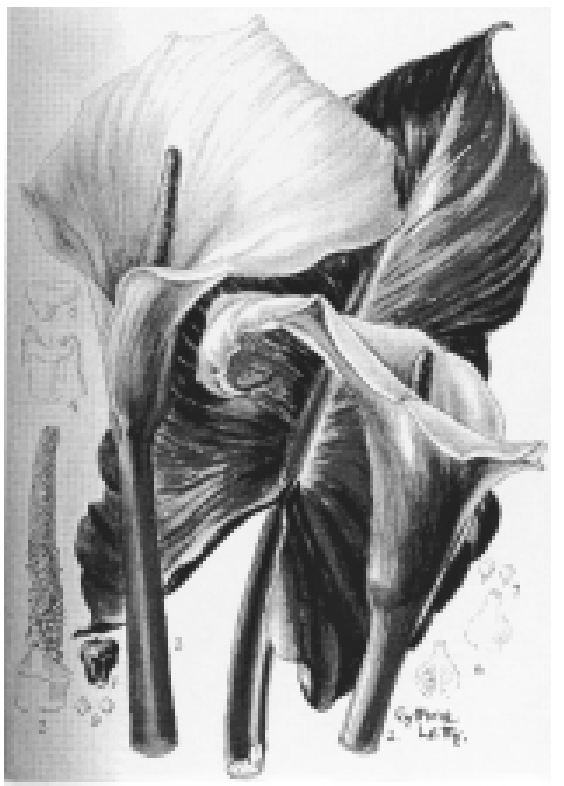

Fig. 1. Z antedeschia aethiopica (L.) Spreng. (Letty, 1973). ground during winter) (Letty, 1973; Tjia 1985).

The evergreen species $Z$. aethiopica with, ovate-cordate solid green leaves and white spathes at least 36 inches $(100 \mathrm{~cm})$ tall has long been used for cut flowers and container plants (Fig. 1). It flowers in summer and late fall into early spring in frost free areas (Letty, 1973; Dole and Wilkins, 1999; T jiaand Funnell, 1986). Cultivar selections include the dwarf selection 'Childsiana', 'Pink $M$ ist' a pink spathe selection, and ' $G$ reen $G$ oddess' with a green spathe. The species hasnaturalized (perennialized) in many countries, e.g., N ew Zealand, Australia, M exico, and California. (D ole and Wilkins, 1999; Tjia, 1985). Zantedeschia aethiopica have solid green leaves and is the only species to have long, branched rhizomes. All other species have compact, diskshaped stems referred to as tubers (L etty, 1973).

Zantedeschia rehmannii has deciduous, narrow, lanceolate leaves which are neither spotted nor lobed (Fig. 2). The 24 inch $(60 \mathrm{~cm})$ tall spathes bloom in summer and range in color from yellow to lemon yellow and pink to dark maroon (Letty, 1973; Funnell, 1993; Tjia, 1985).

Zantedeschia jucunda has deciduous, triangular-hastate leaves that are always spotted (Fig. 3). Spathes are golden yellow with a purple throat at the base and are summer blooming. This species is used mostly as a land-

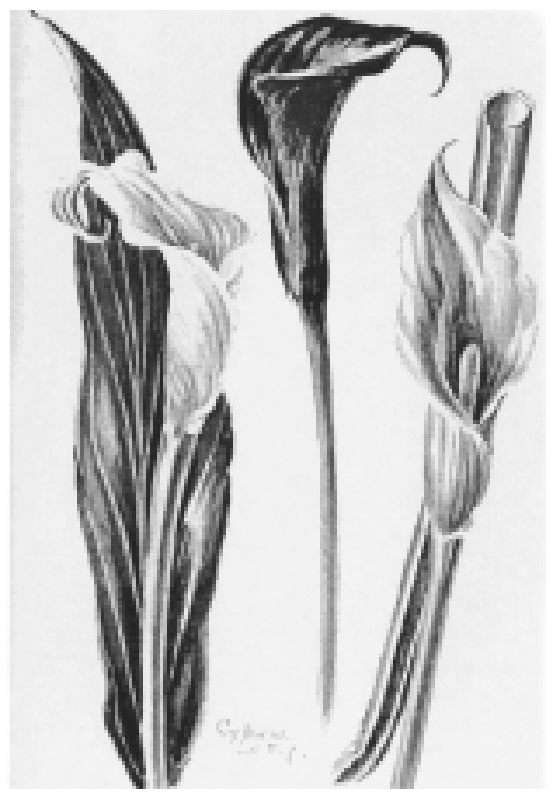

Fig. 2. Z antedeschia rehmanni E ngl. (Letty, 1973). scape plant ( Letty, 1973; Funnell, 1993; Perry, 1989; T jia, 1989).

Zantedeschia elliottiana has deciduous, orbicular-ovate leaves and yellow to gold colored spathes that are about 12 inches $(30 \mathrm{~cm})$ tall, blooming in the summer ( Funnell, 1993; Tjia, 1989; Tjia, 1985; L etty, 1973).

Zantedeschia pentlandii (syn. Z. angustiloba) has deciduous, oblongelliptic to oblong-lanceolate leaves usually without white spots (Fig. 4). Spathes can be white, cream, ivory, pale greenish yellow or yellow, usually with a purple blotch at the base, are up to 24 inches $(60 \mathrm{~cm})$ tall and bloom in the summer ( Letty, 1973; Funnell, 1993; Tjia, 1989).

Zantedeschia odorata has deciduous, ovate to cordate leaves with milkwhite spathes having a green base and sweet scent (Funnell, 1993; Perry, 1989).

Zantedeschia albomaculata hasdeciduous, triangular-hastate leaves and the spathe color rangesfrom creamy to straw colored to pale yellow, with purple interior bases; flower stems can beup to 18 inches $(45 \mathrm{~cm}$ ) tall (Funnell, 1993; Tjia, 1985).

Zantedeschia albomaculata sub. al bomaculata has deciduous, oblonghastate leaves, and a plant height of up to 30 inches $(75 \mathrm{~cm})$ (Fig. 5). The spathes are white, ivory, paleyellow, to coral pink, bloom in the summer and are not widely used commercially (Letty, 1973; Funnell, 1993; Tjia, 1989).

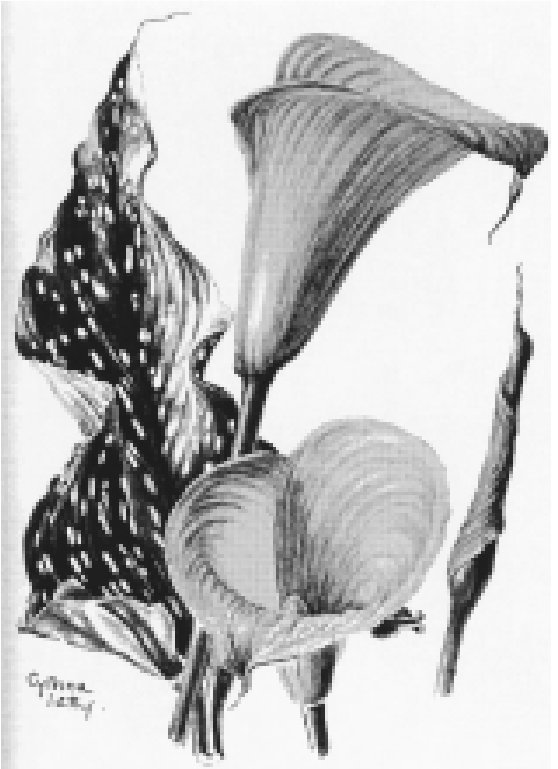

Fig. 3. Z antedeschia juncunda Letty (Letty, 1973). 


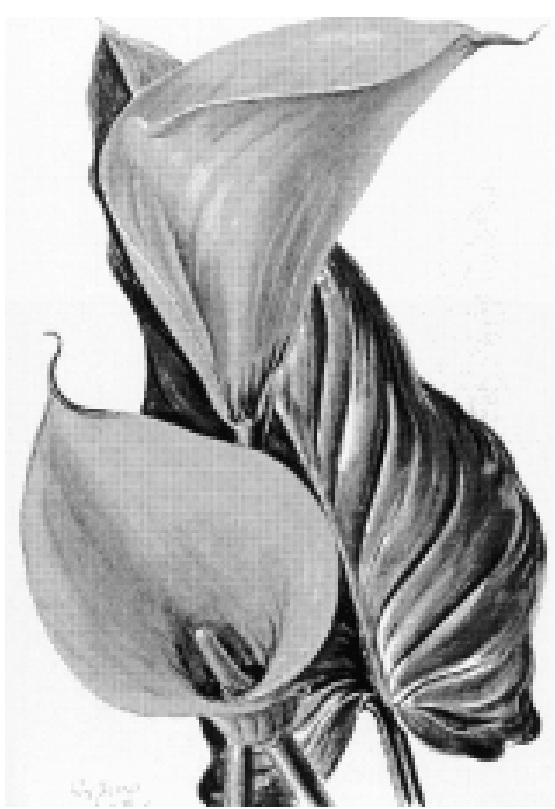

Fig. 4. $Z$ antedeschia pentlandii (Watson) Wittm. (L etty, 1973).

Zantedeschia albomaculata sub. macr ocar pa has deciduous, triangularhastate leaves that are sparsely speckled (Fig. 6). The summer blooming spathes are medium and are either cream or straw colored (Tjia, 1989; Letty, 1973).

Zantedeschia albomaculata sub. valida has deciduous, ovate-cordate to ovate-obicular-cordateleaves, and a plant height of up to 28 inches $(70 \mathrm{~cm})$ (Fig. 7). Thespathesareivory to cream colored with a purple area at the inside of the base and bloom in the summer (Letty, 1973; Funnell; 1993; Tjia, 1989).

In addition to theabove, thereare other cultivars and hybrids commercially available that have characteristics highly suited to flowering potted plant production (T able 1) (Funnell, 1993; Golden State Bulb Growers, 1994; van Scheepen, 1991).

\section{Environmental requirements}

The effects of light intensity, photoperiod, and temperature on flowering and growth habit of calla vary between species and cultivar. Light intensity hasbeen studied on ' $M$ ajestic Pink', 'Pink Perfection', and 'Pacific Pink' (Armitage, 1991). These cultivars produced a similar flower number at ambient light and 55\% shade; however flower number was significantly reduced at $67 \%$ shade. Flower stem number of 'Black $M$ agic' decreased as

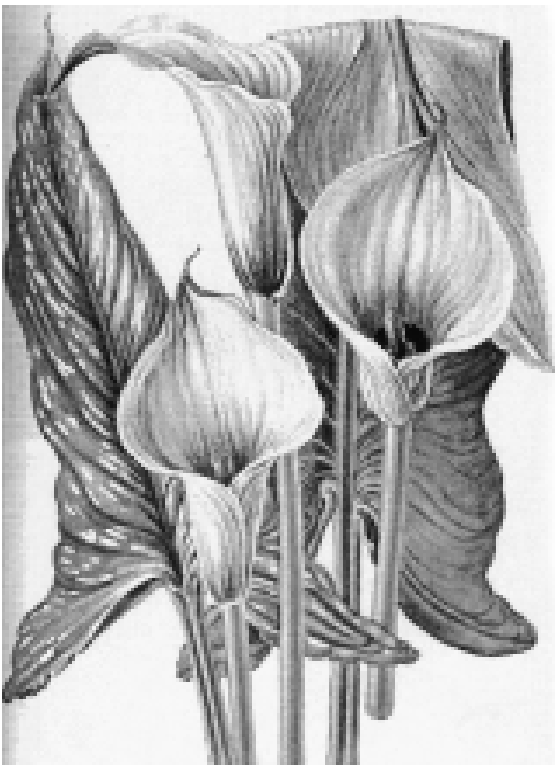

Fig. 5. Z antedeschia albomaculata (H ook.) Engl. subsp. albomaculata showing two forms of leaf (Letty, 1973).

light levels decreased from ambient to $55 \%$ shade and from $55 \%$ to $67 \%$ shade. 'Best Gold' accumulated more dry matter when grown under a combination of either low photosynthetic photon flux (PPF) and cooler temperatures or high PPF and warmer temperatures, which parallels the PPF diversity of its natural habitats (Funnell et al., 1998). I n general, recommended light intensities are 2,500 to 5,000 fc (500 to $1000 \mu \mathrm{mol} \cdot \mathrm{s}^{-1} \cdot \mathrm{m}^{-2}$ ) (De $\mathrm{H}$ ertogh, 1996). In areas where high temperatures are problematic, light intensities can be reduced to 2,500 to $3,500 \mathrm{fc}\left(500\right.$ to $700 \mu \mathrm{mol} \cdot \mathrm{s}^{-1} \cdot \mathrm{m}^{-2}$ ) and in cooler areas 4,000 to $4,500 \mathrm{fc}$ (800 to $900 \mu \mathrm{mol} \cdot \mathrm{s}^{-1} \cdot \mathrm{m}^{-2}$ ) are suggested (D ole and Wilkins, 1999).

There has been some debate concerning dormancy and flowering of calla. Early studiessuggested that there was no dormancy and that year-round production of flowers could be achieved in greenhouses or under protection as long as temperatures are above $60^{\circ} \mathrm{F}\left(15.6^{\circ} \mathrm{C}\right)$ and below $80^{\circ} \mathrm{F}$ $\left(26.7^{\circ} \mathrm{C}\right)$ (Post, 1959; Wilkins, 1985). Rhizomes of Z. aethi opica 'C hildsiana' 0.4 inches $(1 \mathrm{~cm})$ in size produced flowers that were smaller and shorter than flowers produced from larger rhizomes 0.75 to 1 inch (2 to $3 \mathrm{~cm}$ ) (Welsh et al., 1988). They also found that the time of planting, either before or after drying the rhizomes, did not affect flower sizeor plant height. $\mathrm{H}$ owever, rhizomes of Z. elliottiana and Z.

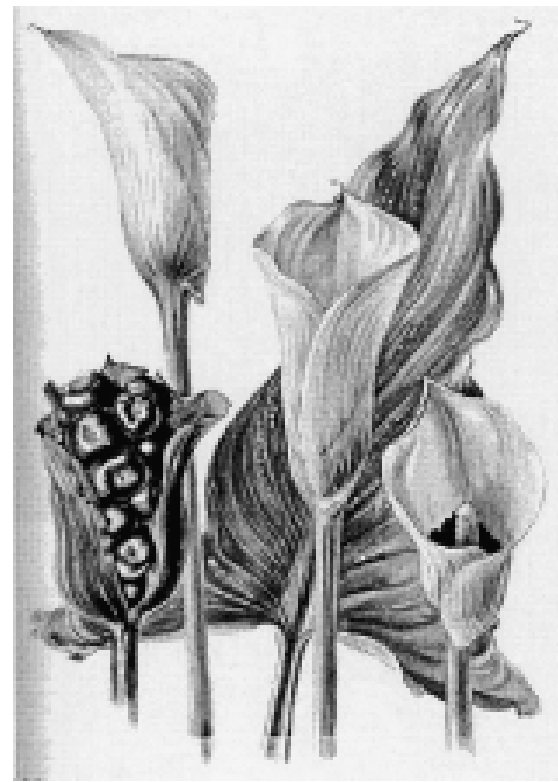

Fig. 6. Z antedeschia albomaculata (H ook.) E ngl. subsp. macrocarpa (Engl.) Letty (Letty, 1973).

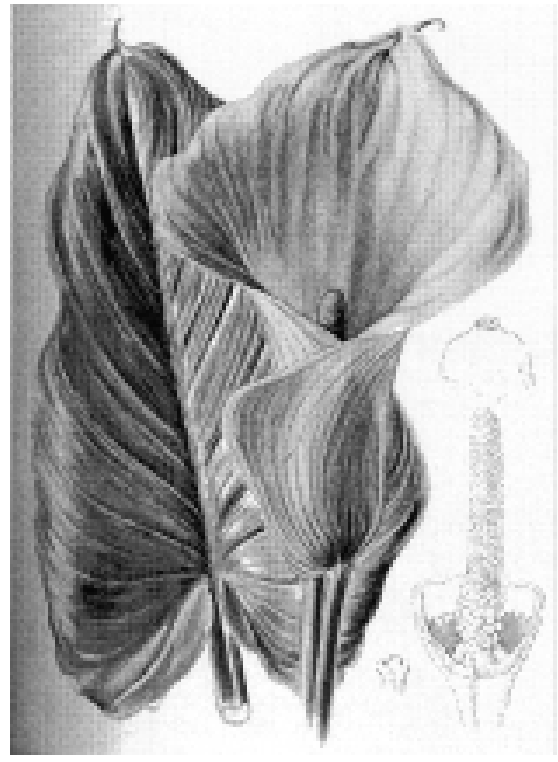

Fig. 7. Z antedeschia albomaculata (H ook.) Engl. subsp. valida L etty (L etty, 1973).

rehmanii replanted immediately after leaf removal, did not grow (C orr and Widmer, 1988). Zantedeschia elliottiana stored dry at 41,64 , or 75 ${ }^{\circ} \mathrm{F}\left(5,18\right.$, or $\left.24^{\circ} \mathrm{C}\right)$ caused a significant reduction in flowering, but, there was no significant reduction in flowering when stored at $54{ }^{\circ} \mathrm{F}\left(12{ }^{\circ} \mathrm{C}\right)$ (Funnell et al., 1988). Zantedeschia rehmannii 'Pink Satin' produced the most flowers after dry storage at $41^{\circ} \mathrm{F}$ $\left(5^{\circ} \mathrm{C}\right)$, with reduced flowering at the higher temperatures. Flowering was significantly greater for tubersthat were 
T able 1. Z antedeschia species and cultivars used for commercial production (T. L ukens, personal communications; van Scheepen, 1991).

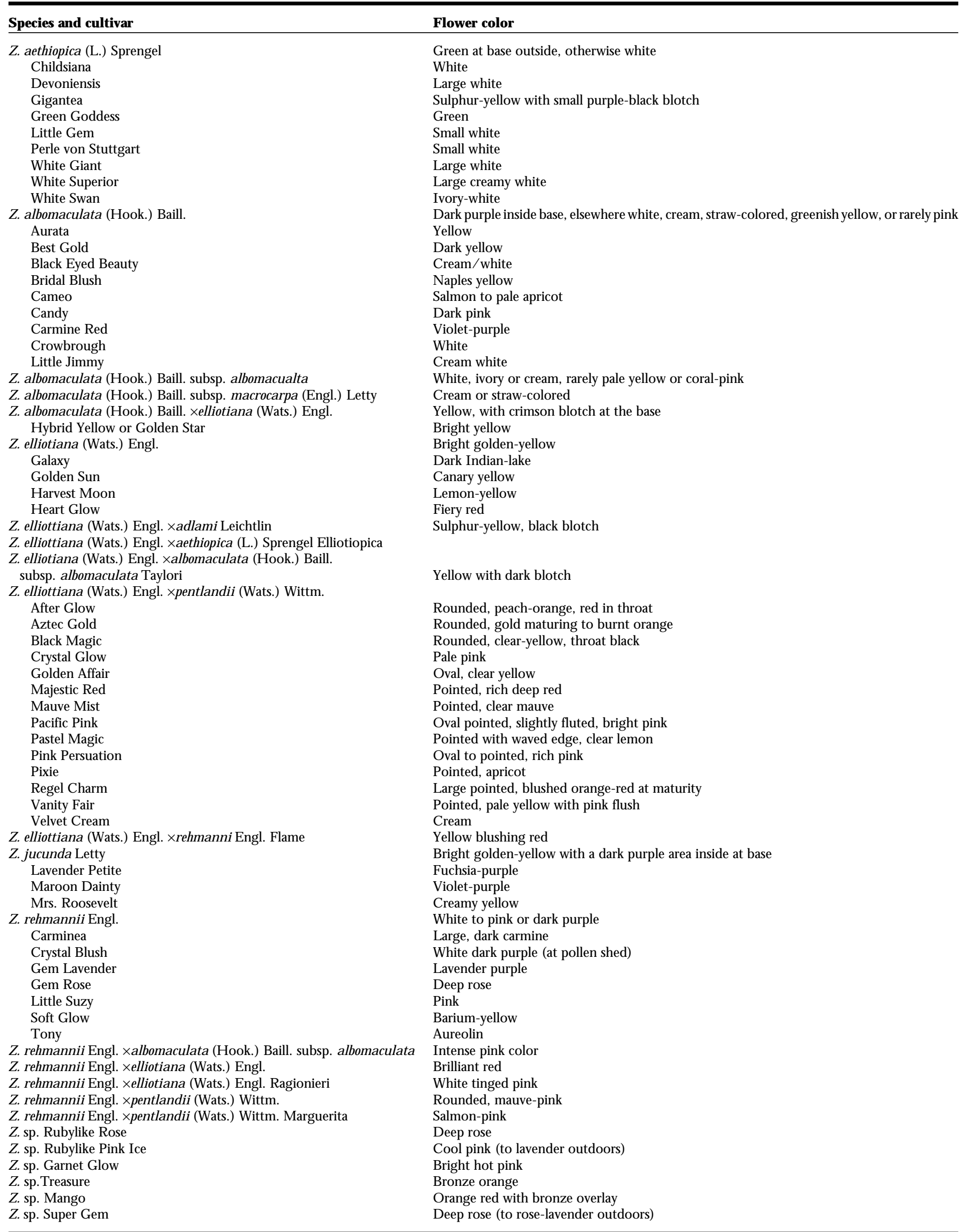


moist-stored at the sametemperatures. Thus, the optimum storage temperature and type of storage environment varies between Zantedeschia species. Although long term storage reduced theflowering potential of Z. elliottiana and $Z$. rehmanii 'Pink Satin', the time to emergence and flowering decreased for 'BestG old' (Funnell and Go, 1993). It is assumed that reserve carbohydrate depletion is responsible for the flowering time span of various species and hybrids of calla (D ole and Wilkins, 1999).

$\mathrm{N}$ ight interruption of calla caused aslight increase in flower number (data not reported) (Greene et al., 1932). A more recent study indicated that photoperiod (night interruption with a red to far-red ratio of $8: 1$ ) had no significant effect on the number of leaves or shoots, the number of leaves before first flower, date of first flower, or total number of flowers in the first growth cycle of $Z$. elliotiana and $Z$. rehmannii. However, plants grown with a night interruption were taller than those grown under short days (Corr and Widmer, 1990).

Calla can be forced to flower at any time of year if soil temperaturesare maintained at $55^{\circ} \mathrm{F}\left(13^{\circ} \mathrm{C}\right)$ minimum and air temperatures are less than 77 ${ }^{\circ} \mathrm{F}\left(25^{\circ} \mathrm{C}\right)$ (Welsh, 1991). H owever, Z. elliottiana grown at an air temperature of $70{ }^{\circ} \mathrm{F}\left(21^{\circ} \mathrm{C}\right)$ flowered first, followed by those at $59^{\circ} \mathrm{F}\left(15^{\circ} \mathrm{C}\right)$. Plants grown at $50^{\circ} \mathrm{F}\left(10^{\circ} \mathrm{C}\right)$ did not flower until temperaturewasincreased above $59{ }^{\circ} \mathrm{F}\left(15^{\circ} \mathrm{C}\right)$ (Post, 1936). Zantedeschia rehmannii grown at an air-medium temperature of $68 / 77^{\circ} \mathrm{F}$ $\left(20 / 25^{\circ} \mathrm{C}\right)$ flowered sooner and were taller with longer pedunclesthan those grown at $59 / 57^{\circ} \mathrm{F}\left(15 / 14^{\circ} \mathrm{C}\right.$ ) (Corr and Widmer, 1990). There was no effect of temperature, however, on any characteristic of Z. elliottiana growth. Golden State Bulb Growers (1999) recommend a set of temperature regimes for optimal growth and flowering: 1) from planting to 2 -inch $(5-\mathrm{cm})$ or 3-inch $(7.6-\mathrm{cm})$ sprouts; 75 to 80 ${ }^{\circ} \mathrm{F}\left(24\right.$ to $\left.27^{\circ} \mathrm{C}\right)$ days and nights, 2) after leaf unfurling: 70 to $75^{\circ} \mathrm{F}(21$ to $24^{\circ} \mathrm{C}$ ) days: 55 to $65^{\circ} \mathrm{F}\left(13\right.$ to $\left.18^{\circ} \mathrm{C}\right)$ nights, 3) flower coloring (use high light): 65 to $70^{\circ} \mathrm{F}\left(18\right.$ to $21^{\circ} \mathrm{C}$ ) days 50 to $55^{\circ} \mathrm{F}\left(10\right.$ to $\left.13^{\circ} \mathrm{C}\right)$ nights.

The induction of a floral state in calla requires a trigger level of gibberellin to proceed (Funnell, 1993). It has been suggested that storage of rhizomes may affect the gibberellin levels endogenously, sensitivity to exogenous levels of gibberellin, and/ or the plants ability to absorb gibberellin (Funnell, 1993). The application of gibberellic acids (GA) isrecommended for increased flowering of calla as a cut flower (Welsh and Clemens, 1992) and for flowering potted plants (Corr and Widmer, 1987; Funnell et al., 1992; Reiser and Langhans, 1993). $\mathrm{H}$ owever, commercially availableforms of $G A$ are not currently labeled for use on calla.

\section{Cultural requirements}

Traditionally, propagation of calla has been by division of rhizomes or tubers which was conducive to spread of viruses and bacterial diseases, especiallyErwinia sp. (Brown, 1990; Welsh and Clemens, 1992). H ybridizing, cultural techniques for preventing or suppressing disease, increased seed production, and the use of tissue culture have radically changed production practices. I $n$ vitro or tissue culture techniques for propagation of calla are outlined by Cohen (1981) and RuizSifre et al. (1996).

To produce a tuber 1.5 to 2.4 inches $(4$ to $6 \mathrm{~cm}$ ) in diameter (flowering size) two growing cycles of 16 weeks (minimum) of active growth followed by a rest period are required (Welsh and Clemens, 1992). While about $80 \%$ of tissue cultured tubers emerge and flower after one growing cycle, these are not large enough for a single tuber to produce a marketable 4-inch $(10-\mathrm{cm})$ pot (D oleand Wilkins, 1999). The number of days between planting date and bloom decreasesthe later in the year the planting date (Golden State Bulb Growers, 1999).

After chemical treatment for disease (see D isease and I nsect section), some cultivars should be treated with GA to increase the number of flowering shootsand flowersper shoot (W elsh and Clemens, 1992). Application of $\mathrm{GA}_{3}$ (ProGibb, Abbott Laboratories, $\mathrm{N}$ orth C hicago, III.) at 50 to $100 \mathrm{ppm}$ $\left(\mu \mathrm{L} \cdot \mathrm{L}^{-1}\right)$ as a 30 -min preplant dip increased stem number per tuber of $Z$. elliotiana and Z. rehmannii (Tija, 1985). Soaking tubers in $\mathrm{GA}_{3}$ before planting increased number of shoot bearing flowers and the number of flowers per shoot (Corr and Widmer, 1987). I n contrast, foliar sprays of $\mathrm{GA}_{3}$ did not significantly affect plant growth or flowering. Application of $\mathrm{GA}_{3}$ at
100 and 500 ppm asa 10 -min dip of $Z$. rehmanii superba 'Pink', Z. elliottiana xmaculata 'Yellow' and $Z$. albomaculata 'W hite' tubers, increased flowering and flower number as treatment concentrationsincreased ( $R$ eiser and $L$ anghans, 1993). G ibberellic acid at $25 \mathrm{ppm}$ and Promalin $\left(\mathrm{GA}_{4+7}+\mathrm{BA}\right.$, Abbott L aboratories, $\mathrm{N}$ orth Chicago, III.) at $100 \mathrm{ppm}$ applied as a preplant dip to 'Galaxy', a Z. rehmannii-like selection, produced the greatest increase in total flower number (Funnell et al., 1992). A 10-s immersion of rhizomes was as effective as 1 or 30 min immersions at the $\mathrm{GA}_{3}$ and Promalin concentrations used in the same experiment. Thus, quick dips or spray applications of rhizomes are feasiblemethods of treatment for increasing flower number of calla. For cutflower production, GA at $150 \mathrm{ppm}$ can be applied as a spray to established plantings after sprout emergencewhen leaves are unfurling or expanded (Golden State Bulb Growers, 1999). Soil beds or pots can be drenched with a 100 ppm GA solution during dormancy. Soil should be moderately wet at time of drench.

Calla should be planted about 2 inches $(5 \mathrm{~cm})$ below the surface of a well-drained and sterilized growing medium with high organic matter and apH of 6 to 6.5 (Kuehny et al., 1996). D rench within $3 \mathrm{~d}$ of initial watering to control Erwinia carotovora subsp. carotovora (Jones) Bergey, $X$ anthomonas D owson, or R hizoctonia $D C$, the three major pathogens contributing to the soft rot syndrome. A combination of three commercial productsisrecommended for best control of the three diseases, respectively: 1) streptomycin sulfate (Agri-M ycin 17, M arman U SA, Tampa, Fla.) at 100 to $200 \mathrm{ppm}$ [0.5 to $1 \mathrm{lb} / 100 \mathrm{gal}(0.6$ to $\left.1.2 \mathrm{~g} \cdot \mathrm{L}^{-1}\right)$ ], 2) fosetyl-Al (Aliette, Rhone-Poulenc $A g$, Research T riangle Park, N.C.) at $13 \mathrm{fl} \mathrm{oz/} 100 \mathrm{gal}(1.0$ $\mathrm{mL} \cdot \mathrm{L}^{-1}$ ), 3) iprodione (C hipco 26019, Rhone-Poulenc, Research Triangle Park, N.C.) at $6.5 \mathrm{fl} \mathrm{oz/} 100$ gal $(0.5$ $\mathrm{mL} \cdot \mathrm{L}^{-1}$ ).

Recommended planting densities and tuber sizes for producing salable pots are: 4 -inch $(10-\mathrm{cm})$ pot $=1$ tuber 1.75 to 2 inches $(4.5$ to $5 \mathrm{~cm})$ or 2 tubers 1.25 to 1.5 inches ( 3.2 to 3.8 $\mathrm{cm})$ in diameter, 6 -inch $(15.25-\mathrm{cm})$ pot $=1$ tuber 2.5 inches $(6.4 \mathrm{~cm})$ or 2 tubers 1.75 inches $(4.5 \mathrm{~cm})$ or 3 tubers 1.5 inches $(3.8 \mathrm{~cm})$ in diameter, 8- 
inch $(20.3-\mathrm{cm})$ pot $=3$ tubers 2 inches $(5 \mathrm{~cm}$ ) in diameter (Golden StateBulb Growers, 1999). Plants can be grown pot-to-pot until leavestouch, and then spaced on 6 -inch $(15-\mathrm{cm})$ centers. Spacing needs may vary by cultivar.

Recommended planting densities and rhizome sizes for cut flower production remaining in the field for 2 to 3 years are: 1.5 - to 1.75 -inch (3.8- to 4.3-cm) tuber $=5$-inch $(12.7-\mathrm{cm})$ centers, 1.75 - to 2 -inch $(4.3-$ to $5-\mathrm{cm})$ tuber $=6$-inch $(15.2-\mathrm{cm})$ centers, 2 to 2.5 -inch $(5-$ to $6.4-\mathrm{cm})$ centers, and 2.5-inch $(6.4-\mathrm{cm})$ tuber and up $=8$ inch $\times 10$-inch $(20.3-\times 25.4-\mathrm{cm})$ center (Golden State Bulb Growers, 1999).

Calla grown as flowering pot plants should be fertilized with a complete liquid feed of 100 to $200 \mathrm{ppm} \mathrm{N}$ of a nitrate-nitrogen based fertilizer (Golden State Bulb Growers, 1999; Kuehny et al., 1996). A 5-month, controlled-release fertilizer (23N-7.8P$30.7 \mathrm{~K}$ ) was incorporated in a 50 pine bark : 30 pumice: 20 peat (by volume) medium at 0.5 and $2 \mathrm{lb} / \mathrm{yd}^{3}(0.30$ and $\left.1.20 \mathrm{~kg} \cdot \mathrm{m}^{-3}\right)$ of $\mathrm{N}$ and 0.08 and 0.14 and $0.54 \mathrm{lb} /$ cubic yard $\left(0.32 \mathrm{~kg} \cdot \mathrm{m}^{-3}\right)$ $P$ (Clemens et al., 1998). A greater flower number, greater bloom fresh weight, more advanced shoot development, shorter time to flower, and greatest plant survival was indicated at the low $\mathrm{N}$ level of $\mathrm{Z}$. albomaculata 'Starlights'. It is important not to overwater the medium before shoot emergence. I t must be kept moist and not allowed to dry completely. If the tubers are too wet the incidence of disease can increase.

Field grown calla require $\mathrm{N}$ and $\mathrm{K}$ in the greatest amounts and broadcast rates of $268 \mathrm{lb} \mathrm{N}, 40 \mathrm{lb} \mathrm{P}$, and $357 \mathrm{lb}$ $\mathrm{K}$ per acre $(300 \mathrm{~kg} \mathrm{~N}, 45 \mathrm{~kg} P$, and 400 $\mathrm{kg} \mathrm{K}$ per hectare) are suggested for production of Z. elliottiana (Clark and Boldingh, 1991). This should be applied as a slow-release or soluble fertilizer, either as a basal dressing or immediately after planting before the emergence of shoots.

No pinching, disbudding or support is required. A plant growth regulator (PGR) however, may be necessary for height control when calla are grown as flowering potted plants (Kuehny et al., 1996). To be effective, PGRs must be applied as a drench for uptake by theroot system. Foliar sprays are not adequately metabolized and the PGR efficacy is minimal. O ptimal growth inhibition was achieved with a drench of $4 \mathrm{mg}$ a.i. Bonzi (paclobutrazol, U niroyal Chemical, M iddlebury, Conn.)/ per6.7-inch (17$\mathrm{cm})$ pot $(28,350 \mathrm{mg}=1.0 \mathrm{oz})$, while A-Rest (ancymidol, SePRO, Carmel, Ind.) at 1, 2, 3 or $4 \mathrm{mg}$ a.i./ 6.7-inch pot had no affect (Tjia, 1987). A soil drench of $0.5 \%$ or $1.0 \%$ solutions of paclobutrazol when shoots were 0.75 and 1.2 inches $(2$ and $3 \mathrm{~cm}$ ) long, significantly limited plant height of $Z$. rehmannii and limited flower number if not treated with $\mathrm{GA}_{3}$ (Corr and Widmer, 1991). A 10-min GA $\mathrm{A}_{3}$ preplant soak however, overcame the effect of paclobutrazol. A combination of a 100-ppm, 10-min $\mathrm{GA}_{3}$ preplant soak and a drench of $2 \mathrm{mg}$ a.i. per 6 inch $(15-\mathrm{cm})$ pot of paclobutrazol was suggested for producing a quality crop of $Z$. R ehmanii superba 'Pink' and Z. albomaculata 'White'. Sumagic (uniconzole) at $2 \mathrm{mg}$ a.i. per 6 -inch pot also produced satisfactory results (Reiser and Langhans, 1993). D renches of 0.5 to $4 \mathrm{mg}$ a.i. per 6 -inch $(15-\mathrm{cm})$ pot of paclobutrazol are recommended by Golden State Bulb Growers (1999) before shoots are 2.5 inches $(5 \mathrm{~cm})$. A preplant spray of $1.8 \%$ Promalin at $100 \mathrm{ppm}$ (1.3 tablespoons/ gal, $5.5 \mathrm{~mL} \cdot \mathrm{L}^{-1}$ ) mixed with copper hydroxide $37.5 \%$ at 3 tablespoons/gal (20 mL $\left.\cdot \mathrm{L}^{-1}\right)$ or copper oxychloride $50 \mathrm{WP}$ at $0.4 \mathrm{oz} / \mathrm{gal}$ ( 3 $\left.g \cdot L^{-1}\right)$ is currently recommended for quality production of calla (Kuehny et al., 1996; Beckman and L ukens, 1997).

For cut flower production, the safest and most effective preemergent herbicides for Zantedeschia are terbumeton/ terbuthylazine at 1.34 and $2.67 \mathrm{lb} /$ acre $\left(1.5\right.$ and $3.0 \mathrm{~kg} \cdot \mathrm{ha}^{-}$ $\left.{ }^{1}\right)$, simazineat $1.78 \mathrm{lb} / \mathrm{acre}(2.0 \mathrm{~kg} \cdot \mathrm{ha}$ $\left.{ }^{1}\right)$ or oxadiazon at $1.34 \mathrm{lb} /$ acre $(1.5$ $\mathrm{kg} \cdot \mathrm{ha}^{-1}$ ) (Ingle and Bussell, 1991).

\section{Diseases}

Themost common disease of calla isa bacterial soft rot caused by Erwinia carotovora subsp. carotovora (Kuehny et al., 1998; Corr, 1990; Corr, 1993). Thisbacteriacausesa foul-smelling rot of rhizomes or tubers, leaves and flowers, and infected plants will topple at soil level. Before planting, tubers can be immersed in a disinfectant or antibiotic to control erwinia infection (Reiser and L anghans, 1993). Tubers treated with sodium hypochlorite, streptomycin and chloramphenicol also had reduced erwinia problems ( $\mathrm{T}$ jia and Jierwiriyipant, 1988). A 30-min 200-ppm streptomycin dip provided the best control of erwinia of calla tubers, while a 1-h 10\%formaldehyde dip was second best (Kuehny et al., 1998). Chemical treatments did not affect days to emergence or final plant growth.

O ther lesser diseases are crown rot (Pellicularia filamentosa Cooke), which causes a soft decay of the lower half of the main rhizome or tuber and thick feeding roots. Cer cospora richardiaecola Atk., C. callae Peck \& G.W. Clinton, and Phyllostricta richardsoniae Ellis \& Evech. affect leaves, stalks and flowers. Symptoms of root rot (Phytophthora richardiae Buisman) appear on thelower or outer leaves at the same time plants begin to flower. Storage rot (Pythium ultimum Trow) is most common on $Z$. rehmannii and Z. elliotiana. Tomato spotted wilt virus may also infect calla with symptoms of chlorotic to pale white streaks and circular lesions becoming necrotic between the veins of leaves (Pirone, 1978).

\section{Insects}

There are few insects that disturb calla. The grape mealybug (Pseudococcus maritimus Ehrhorn), longtailed mealybug ( $P$. longispinus Targioni Tozzetti), bulb mite ( $R$ hizoglyphus echinopus Fumouze \& Robin), banded greenhouse thrip (H ercinothripsfemoralisO .M . Reuter) and greenhouse thrip $(H$. haemorrhoidalis Bouche) are among the insects that have been reported to damage calla (Pirone, 1978).

M ealybugsaresoft-bodied insects that produce a waxy powder over their bodies and have preferred feeding sites on the inside of the leaf sheath of calla (Powell and Lindquist, 1997). Bulb mites have pearly white bodies and move slowly on short, reddish legs. Plant injury through feeding damage has been suggested as a mode for secondary infection of plant pathogens such as those mentioned previously (Powell and Lindquist, 1997). Thrips may feed on developing leaves and flowers, expanded leavesand flowers, and on pollen of calla. These feeding habits will cause distortion of flowers and leaves or the appearance of silvery areas on leaves (Powell and Lindquist, 1997). Transmission of tospoviruses tomato spotted wilt virus (TSWV) and impatiens necrotic spot 
virus (I N SV) by thrips on calla have not been reported.

\section{Physiological disorders}

Gibberellic acid treatments can cause flower deformities including misshapen spathes, doublespathesand colored leaves ( partially initiated flowers) by up to $15.5 \%$ at 100 and $22 \%$ at 500 ppm (Reiser and L anghans, 1993). Similar results have also been reported by Corr and Widmer (1991). The use of Promalin may not induce as many deformed spathes (Golden State Bulb Growers, 1999).

\section{Postproduction and postharvest}

Flowering POTTED PLANTS. Zantedeschia aethiopica 'C hildsiana' removed from the greenhouse when the spathe was green and at least partially enclosed by the leaf sheath and then held at $75-\mathrm{fc}\left(5 \mu \mathrm{mol} \cdot \mathrm{s}^{-1} \cdot \mathrm{m}^{-2}\right)$ for $12 \mathrm{~h}$ at $68^{\circ} \mathrm{F}\left(20^{\circ} \mathrm{C}\right)$, produced quality flowers for $26 \mathrm{~d}$ with only $13 \%$ not develo ping (Plummer et al., 1990). Plants removed from the greenhouse when the spathe was white, fully open but with no pollen shed had a postproduction life of only $11 \mathrm{~d}$. H ybrids stored at 37 to $39^{\circ} \mathrm{F}\left(3\right.$ to $4{ }^{\circ} \mathrm{C}$ ) had good post production life for $7 \mathrm{~d}$ and quality plants were retained $8 \mathrm{~d}$ after they were removed from postproduction storage (N owak and Rudnicki, 1990).

CUt FLowers. The best method of harvesting calla flowers is to cut the stems asfar down the plant as possible. A plant should be harvested when the spathes are 0.75 to fully open and about $1 \mathrm{~d}$ before pollen shed. When flowers are harvested and placed in water only, the stems tend to split. Thiscan be prevented by adding sugar at $0.4 \mathrm{oz} /$ gallon $\left(40 \mathrm{~g} \cdot \mathrm{L}^{1}\right)$ and 100 ppm 8- hydroxyquinoline citrate and pulsed in this solution for 8 to $12 \mathrm{~h}$ and hardened at 41 to $50^{\circ} \mathrm{F}\left(5\right.$ to $10^{\circ} \mathrm{C}$ ) overnight (Tjia, 1985). Theflower life of Z. aethi opica was 6 to $7 \mathrm{~d}$, while $Z$. elliottiana began to turn green after 7 to $8 \mathrm{~d}$ (Tjia and Funnell, 1986). Ethylene had no effect on the regreening ofZ. elliottiana 'Best Gold', and ' $\mathrm{H}$ elen $\mathrm{O}$ 'Connor' and no detectable ethylene was produced by the three hybrids (Funnell and Downs, 1987).

\section{Conclusion}

Callas are a minor flowering pot plant and cut flower that continue to increase in popularity and offer the industry and the public an alternative in the floriculture market. A great deal of research hashelped establish a good set of production protocols so that calla can be produced with relatively few problems. Continued breeding work has hel ped improve disease resistance, flower number, flower size and plant height. Although there are a large number of calla species and hybrids available, producers should be careful to select those calla that have been bred for improved disease resistance and plant quality, and purchase bulbsfrom areputable source. A reas of further research include continued improvement of disease resistance and chemical treatments, determining the factors that control bud dormancy and floral inititiation, and development of programs for year-round production of calla.

\section{Literature cited}

Armitage, A.M . 1991. Shade affects yield and stem length of field-grown cut-flower species. H ortScience 26(9):1174-1176.

Beckman, P. and T. L ukens. 1997. Simple steps for pot calla success. G rowerTalks 60(12):49, 54.

Brown, J. 1990. California calla breeding. H erbertia 46(2):165-169.

Clark, C.J. and H.L. Boldingh. 1991. Biomass and mineral nutrient partitioning in relation to seasonal growth of Zantedeschia. Sci. H ort. 47:125-133.

Clemens, J.D ., D.J. D ennis, R.C. Butler, M.B. Thomas, A. Ingle, and T.E. Welsh. 1998. M ineral nutrition of Zantedeschia plants affects plant survival, tuber yield, and flowering upon replanting. J. Hort. Sci. Biotechnol. 73(6):755-762.

Cohen, D. 1981. Micropropagation of zantedeschia hybrids. Proc. Intl. Plant Propag. Soc. 31:312-317.

Cohen, D. and J.L. Yao. 1996. In vitro chromosomedoubling of nineZantedeschia cultivars. Plant Cell Tissue Organ Cult. 47:43-49.

Corr, B.E. 1990. Calla lilies as flowering potted plants. Tenn-Flower-G rowers-N ews $4(4): 2-3$.

Corr, B.E. 1993. Zantedeschia research in theU nited States: Past, present and future. Acta H ort. 337:177-187.

Corr, B.E. and R.E. Widmer. 1987. Gibberellic acid increases flower number in Zantedschia elliottiana and Z. rehmannii. H ortScience 22(4):605-607.
Corr, B.E. and R.E. Widmer. 1988. Rhizome storage increases growth of Zantedeschia elliottiana and Z. rehmannii. H ortScience 23(6):1001-1002.

Corr, B.E. and R.E. Widmer. 1990. Growth and flowering of Zantedeschia elliottiana and Z. rehmannii in response to environmental factors. HortScience 25(8):925927.

Corr, B.E. and R.E. Widmer. 1991. Paclobutrazol, gibberellic acid, and rhizome size affect growth and flowering of Zantedeschia. H ortScience26(2):133-135.

Dole, J.M. and H.F. Wilkins. 1999. Zantedeschia, p. 550-555. In: Floriculture; principles and species. Prentice $\mathrm{H}$ all, U pper Saddle River, N .J .

De H ertogh, A. 1996. Zantedeschia (calla lily), p. C163-172. In: Holland bulb forcer's guide. 5th ed. I ntl. Flower Bulbs Ctr., H illegom, The N etherlands.

Funnell, K.A. 1993. Zantedeschia, p. 683704. In: A.A. D eH ertogh and M. LeN ard (eds.). The physiology of flower bulbs. Elsevier, Amsterdam, The N etherlands.

Funnell, K.A. and C.G. Downs. 1987. Effect of ethylene on spathe regreening in Zantedeschia hybrids. HortScience 22(6):1333.

Funnell, K.A. and A.R. Go. 1993. Tuber storage, floral introduction, and gibberellin in Zantedeschia. Acta H ort. 337:167172.

Funnell, K.A., B.R. M acK ay, and C.R.O. Lawoko. 1992. Comparative effects of promalin and $\mathrm{GA}_{3}$ on flowering and development of Zantedeschia 'Galaxy'. Acta Hort. 292:173-179.

Funnell, K.A., B.O . Tjia, C.J. Stanley, D. Cohen, and J.R. Sedcole. 1988. Effect of storage temperature, duration, and gibberellic acid on the flowering of Zantedeschia elliottiana and Zantedeschia 'Pink Satin'. J. Amer. Soc. Hort. Sci. 113(6):860-863.

Funnell, K.A., E.W. H ewett, I.J. Warrington, andj .A. Plummer. 1998. Leaf mass partitioning as a determinant of dry matter accumulation in Zantedeschia. J. Amer. Soc. H ort. Sci. 123(6):973-979.

Golden State Bulb Growers. 1994. M iniatrue colored zantedeschias: Guidelines for pot growers. Golden State Bulb Growers, Watsonville, Calif.

Golden State Bulb Growers. 1999. Callafornia callas: Guidelines for pot growers. Golden State Bulb Growers, Watsonville, Calif.

Greene, L., R. Withrow, and M . Richman. 1932. The response of greenhouse crops to electric light supplementing daylight. 
Ind. Agr. Expt. Sta. Bul. 366:20.

H oogasian, C. 1992. In season. Florist 26 (1):15.

Ingle, A. and W.T. Bussell. 1991. Tolerance of zantedeschia lilies to herbicides. Proc. 44th N ew Zealand Weed and Pest Control Conf. p. 138-142.

Kuehny, J.S., W.C. Change, and P. Branch. 1996. M iniature potted zantedeschias. $G$ reenhouse $M$ anagement and Production 17-20 Nov.

Kuehny, J.S., G.E.H olcomb, W.C.Chang, and P.C. Branch. 1998. Chemical treatments to control erwinia soft rot of calla rhizomes. H ortT echnology 8(3):353-356.

Letty, C. 1973. The genus Zantedeschia. Bothalia 11, 1 and 2:5-26.

Liberty Hyde Bailey Hortorium. 1976. $\mathrm{H}$ ortusthird; A concise dictionary of plants cultivated in the U nited Statesand $C$ anada. 3rd ed. M acmillan, N ew York.

N owak, J. and R.M. Rudnicki. 1990. Postharvest handling and storage of cut flowers, florist greens and potted plants. Timber Press, Portland, Ore.

Perry, P.L. 1989. A new species of Zantedeschia (Araceae) from the western cape. S. Afr. J. Bot. 55(4):447-451.

Pirone, P.P. 1978. Zantedeschia aethi opica (calla-lily) disease; virus; disease; insects, $p$. 535-536. D iseases and pests of ornamental plants. 5th ed. Wiley, N ew York.
Plummer, J.A., T.E. Welsh, and A.M. Armitage. 1990. Stages of flower development and postproduction longevity of potted Zantedeschia aethi opica 'C hildsiana'. H ortScience 25(6):675-676.

Post, K. 1936. Further responses of miscellaneousplants to temperature. Proc. Amer. Soc. H ort. Sci. 34:627-629.

Post, K. 1959. Zantedeschia (calla), p. 847851. Florist crop production. O range Judd Publishing, N.Y.

Powell, C.C. and R.K. Lindquist. 1997. Ball pest and disease manual: Disease, insect, and mite control on flower and foliage crops. 2nd ed. Ball Publishing, Batavia, III.

Reiser, R.A. and R.W. Langhans. 1993. Cultivation of Zantedeschia species for potted plant production. Acta $\mathrm{H}$ ort. 337:87-94.

Ruiz-Sifre, G., E. Rosa-M arqez, and C.E. Flores-O rtega. 1996. Zantedeschia aethi opi ca propagation by tissue culture. J . Agr. U niv. Puerto Rico 80(3):193-194.

Shibuya, R. 1956. In: Intercrossing among pink calla, white-spotted calla and yellow calla. Kasai Publishing and Printing Co., Tokyo.

Tjia, B. 1985. H ybrid zantedeschialilies: A potential new crop for Florida. Proc. Fla. State H ort. Soc. 98:127-130.

Tjia, B. 1987. Growth regulator effect on growth and flowering of Zantedeschia rehmannii hyb. H ortScience 22(3):507508.
Tjia, B. 1989. Zantedeschia, p. 697-702. In: A.H. H alevy (ed.). The CRC handbook of flowering, vol. VI. CRC Press, Boca Raton, Fla.

Tjia, B.O. and K.A. Funnell. 1986. Postharvest studies of cut zantedeschia inflorescences. Acta H ort. 181:451-457.

Tjia, B. and U. Jierwiriyipant. 1988. Preplant treatments of calla lily tubers to control erwinia. Fla. O rn. G rowersAssn. N wsl. 11(3):6-7.

Traub, H .P. 1948. ThegenusZantedeschia. Plant Life 4:9-32.

van Scheepen, J. 1991. International checklist for hyacinths and miscellaneous bulbs. Royal General Bulbgrowers' Assn., Alblasserdam, The $\mathrm{N}$ etherlands.

Welsh, T.E. 1991. T heN ew Z ealand C alla. Proc. I ntl. Plant Prop. Soc. 40:478-484.

Welsh, T.E. and J. Clemens. 1992. Protected cropping of Zantedeschia tubersand cutflowers in New Zealand. Acta H ort. 319:335-339.

Welsh, T.E., J.A. Plummer, and A.M. Armitage. 1988. Preliminary evaluation of the dwarf white calla lily as a potted plant. Proc. I ntl. Plant Prop. Soc. 38:384-388.

Wilkins, H .F. 1985. Zantedeschia, p. 523524. In: A.H. H alevy (ed.). CRC handbook of flowering. vol. 4. CRC Press, Boca Raton, Fla. 